\title{
Fungal Genetics Reports
}

\section{A simple modification of the A. nidulans transformation protocol increases the transformation frequency}

\author{
J A. Cockram \\ University of Hull \\ Sealy-Lewis \\ University of Hull
}

Follow this and additional works at: https://newprairiepress.org/fgr

\section{c.) (i) (2)}

This work is licensed under a Creative Commons Attribution-Share Alike 4.0 License.

\section{Recommended Citation}

Cockram, J. A., and . Sealy-Lewis (2000) "A simple modification of the A. nidulans transformation protocol increases the transformation frequency," Fungal Genetics Reports: Vol. 47, Article 24. https://doi.org/ $10.4148 / 1941-4765.1220$

This Brief Note is brought to you for free and open access by New Prairie Press. It has been accepted for inclusion in Fungal Genetics Reports by an authorized administrator of New Prairie Press. For more information, please contact cads@k-state.edu. 


\title{
A simple modification of the A. nidulans transformation protocol increases the transformation frequency
}

\begin{abstract}
After transformation of Aspergillus nidulans with plasmid DNA the transformants are usually incubated at $37 \mathrm{C}$ until transformants appear. We have found that pre-incubation of the transformation plates at room temperature for $24 \mathrm{~h}$ leads to increased transformation frequencies.
\end{abstract}


A simple modification of the Aspergillus nidulans transformation protocol increases the transformation frequency

Jane A. Cockram and Heather M. Sealy-Lewis. Department of Biological Sciences, University of Hull, Hull. HU6 7RX

After tansformanon of Aspergillus nidulans with plasmid DNA the transformants are usually incubated at $37^{\circ} \mathrm{C}$ until transformants appear. We have found that pre-incubation of the transformation plates at room temperature for $24 \mathrm{~h}$ leads to increased transformation frequencies.

The transformation protocol of Tiburn et al. 1983 (Gene 26, 205-221) bas been used in our lab virtually without change since it was developed. Recently we discovered that a simple modification increases the transfonnation frequency.

The results of a typical experiment are shown in Table 1. Details of the protocol not specifically mentioned bere are the same as described in Tilbum er al. Strain H 1326: biA ; argB2; pyroA4; alc4500 was inoculated into Aspergillus glucose mivima? mudium with appropriate supplementation and growa for 16 hours a $25^{\circ} \mathrm{C}$. The mycelium was divided into two portions one of which was treated with Novozyme 234 for $1.5 \mathrm{~h} \mathrm{at} 30^{\circ} \mathrm{C}$ and the other for $1.8 \mathrm{~h}$ at $25^{\circ} \mathrm{C}$. After the protoplast washing procedures the two batches of protoplasts were transformed with $\mathrm{pBluearg}$ (constructed by insertiog the BamHV/Pstl fragment from pIJ 16 containing argB into Bluescript). After transformation and plating out of the protoplasts on selecuve media lacking arginine, half the plates from each treament were immediately incubated at $37^{\circ} \mathrm{C}$, and the other half were left at room teraperature for $24 \mathrm{~h}$ before being transferred to the $37^{\circ} \mathrm{C}$ incubator. As can be seen from Table 1 the plates that were preincubated at room temperature result in at least a 2-fold increase in the transformation frequency. This result has been repeated consistently in our laboratory. This is a simple modification of the protocol and with some plasmids/strains that are difficult to transform any modifiation that increases the frequency may be beneficial. Lowering the protoplasting temperature also seemed to tead to increased transformation frequencies in this experiment.

Table I. Transformation experiment testing protoplasting temperature and regeneration condibons on the transformation frequeacy

\begin{tabular}{clc}
\hline $\begin{array}{c}\text { Proplasting } \\
\text { Temperanire }\end{array}$ & Regeneration Conditions & $\begin{array}{c}\text { Transformants } \\
\mu g / p \text { Bluearg }\end{array}$ \\
\hline $25^{\circ} \mathrm{C}$ & $24 \mathrm{~h}$ at room termp & 65 \\
& then at $37^{\circ} \mathrm{C}$ & 20 \\
$25^{\circ} \mathrm{C}$ & $37^{\circ} \mathrm{C}$ from start & 14 \\
$30^{\circ} \mathrm{C}$ & $24 \mathrm{~h}$ at room temp & \\
& then as $37^{\circ} \mathrm{C}$ & 7 \\
$30^{\circ} \mathrm{C}$ & $37^{\circ} \mathrm{C}$ from start & \\
\hline
\end{tabular}

